\title{
Pollenia moravica (Jacentkovský, 1941) (Diptera: Calliphoridae) recorded from Poland for the first time
}

\author{
Krzysztof SzPILA* and Agnieszka DraBER-MoŃKO** \\ * Nicolaus Copernicus University, Institute of Ecology and Environmental Protection, Department of Animal Ecology, \\ Gagarina9,87-100 Toruin, Poland; e-mail: szpila@biol.uni.torun.pl \\ ** Museum and Institute of Zoology, Polish Academy of Science, Wilcza 64, 00-679 Warszawa, Poland; e-mail: \\ draber@miz.waw.pl
}

\begin{abstract}
Pollenia moravica (Jacentkovský, 1941) is recorded for the first time from Poland. The P. moravica female morphology, previously poorly documented is described and illustrated in detail. High morphological similarity of $P$. moravica with $P$. amentaria (Scopoli, 1763) is confirmed based on Polish specimens. The features useful for separating specimens of these two species are discussed.
\end{abstract}

Key words: Calliphoridae, Pollenia moravica, faunistics, Poland

\section{INTRODUCTION}

Flies of the genus Pollenia Robineau-Desvoidy, 1830 are commonly known as cluster-flies owing to their habit of clustering in dark parts of buildings where they overwinter (Rognes 1987). Cluster-flies may dominate in the blow flies communities what was found in urbicoenose (Draber-Mońko 1985). Some species in the larval stage are known to be parasite or predators of earthworms however there are also evidences they can parasite some other invertebrate as Lepidoptera or Hymenoptera (Rognes 1991).

More than 100 species occur in Palaearctic, Nearctic, Oriental and Australasian regions, while 42 species are known from Palaearctic only (Rognes 1988, 1998). The genus Pollenia with 31 valid species (Rognes 2004), is the most species rich among European blowflies. In Poland, 17 species belonging to this genus have been recorded (Draber-Mońko 2007), but the occurrence of at least a few others is expected.

\section{METHODS}

Pollenia moravica (Jacentkovský, 1941) was collected during field research in xerothermic reserves in southern Poland. Further specimens of this fly were found also in Karczewski's collection deposited in the Museum and Institute of Zoology of the Polish Academy of Science, Warsaw. The whole material includes 25 specimens collected with a sweeping net.

\section{RESULTS}

\section{Pollenia moravica (Jacentkovský, 1941)}

Material. 12 IV 1955, sector 206, forest div. Jędrzejów (UTM: DB52): 1ठ, leg. J. Karczewski; 14 VIII 1955, range Chojny (DB51): 1§ુ, leg. J. Karczewski; 27 III 1957, range Gaj (DB50): $1 \delta$, leg. J. Karczewski; 14 VI 1957, Sobków, wasteland (DB61): 1ठ, leg. J. Karczewski; 13 VIII 2001, "Góry Pieprzowe" reserve (EB51): $7 \AA \AA$ males, 12 12 , leg. K. Szpila; 15 VIII 2001, "Milechowy" reserve (DB53): $2 ð \hat{\jmath}$ males, leg. K. Szpila. 

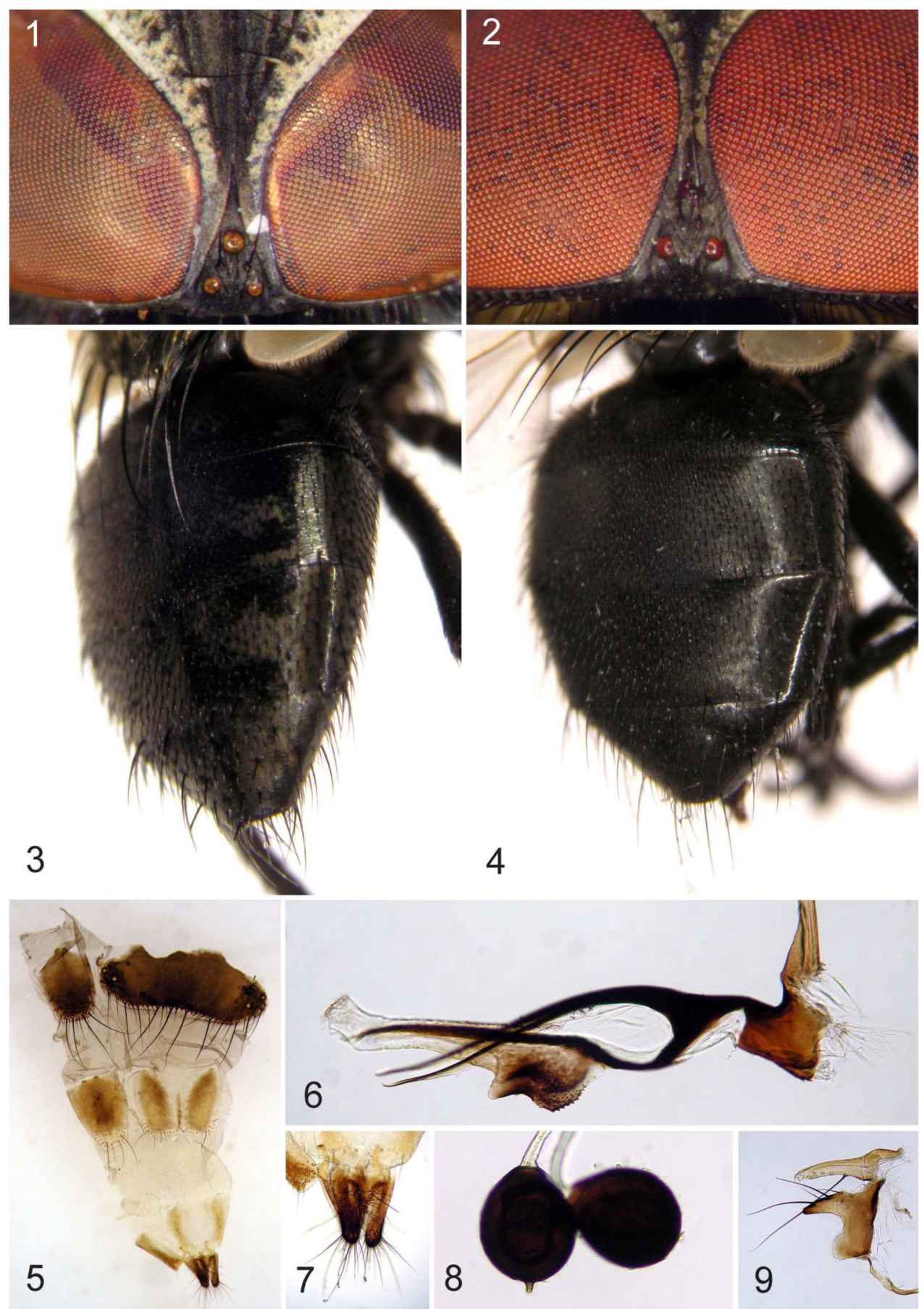

Figs 1-9. Pollenia moravica (Jacentkovský) and Pollenia amentaria (Scopoli): $1-P$. moravica, $\widehat{\imath}$, frons, dorsal view;

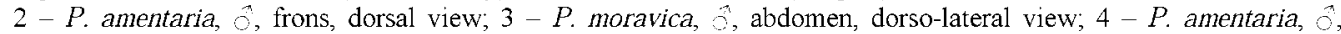
abdomen, dorso-lateral view; $5-P$. moravica, ovipositor, $6-P$. moravica, $A$, phallus; $7-P$. moravica, $千$, tip of ovipositor; 8 - P. moravica, + , spermathecae; $9-$ P. moravica, 3 , pregonite and postgonite. 
Description of female. Terminology follows Merz \& Haenni (2000) with a few modifications proposed by Szpila \& Pape (2007).

Length. 6-9 $\mathrm{mm}$.

Head. Frons $0.330-0.340$ times head width $(n=12)$. Frontal stripe 2 times as wide as each fronto-orbital plate. Fronto-orbital and parafacial plates with pale golden microtrichosity. Facial keel sharp. Facial plate with little yellowish microtrichosity. Anterior part of gena, vibrisal angles, facial ridges, lunula and most of antenna reddish. Parafacial plates with short hairs.

Thorax. Black ground colour, covered with sparse, grayish microtrichosity. Posterior edge of anepisternum with rows of pale hairs behind anepisternal setae. Katepisternum with pale ground vestiture. Chaetotaxy: acrostichals $2+3$, dorsocentrals $2+3$, intra-alars $1+2$, supraalars $1+2$, postalars 2 , outer posthumeral bristle present. Scutellum with 5-6 strong marginal setae, sometimes with a few additional smaller ones. Posterior spiracles dark brown. $t_{1}$ with 2 posteroventral bristles, $t_{2}$ with $2-3$ anterodorsal bristles, $t_{3}$ with $3-5$ anteroventral bristles. Tarsi a little shorter than tibiae. Basicosta black. Node at junction of humeral crossvein and subcostal vein bare below. Cell $\mathrm{R}_{4+5}$ broadly open.

Abdomen. T1+2-T5 with even but sparse microtrichosity, tessellation clearly visible in oblique posterior and lateral view. T7 in ovipositor invaded anteriorly by microtrichiae, and with a mid-dorsal separate sclerotised strip between lateral parts of T7. T8 distally curved medially. ST7 long, broad basally, slender apically, with narrow zone of microtrichiae posteriorly. Spermathecae dark and spherical. Lateral sacs unsclerotised.

\section{Discussion}

Pollenia moravica was described from the Czech Republic (Jacentkovský 1942) and its distribution is restricted to Central Europe and the Balkan Peninsula: Czech Republic, Slovakia, Austria, Hungary, Romania, Croatia and Serbia (Rognes 2004). The identity of $P$. moravica as a valid species has been questioned in the past. Zumpt (1956) in "Die Fliegen der Palaearktischen Region" and Schumann (1986) in the "Catalogue of Palaearctic Diptera" treated the nominal species "Pollenia moravica" as a synonym of Pollenia vespillo (Fabricius, 1794) (currently a synonym of Pollenia amentaria (Scopoli, 1763)). Rognes (1991) hesitantly listed $P$. moravica as a new but questionable synonym of $P$. amentaria and at the same time confirmed a few morphological features separating these two species. In a subsequent cladistic analy sis of Palaearctic species of Pollenia, Rognes (1992) listed P. moravica as a valid species included in the amentaria species-group and finally added this species to the checklist of European blowflies (Rognes 2004). In a recently published monograph concerning Polish Calliphoridae, Draber-Mońko (2004) followed Zumpt (1956), Schumann (1986) and Rognes (1991) and listed P. moravica as a synonym of $P$. amentaria. However, the presence of $P$. moravica in the European checklist convinced the authors of the necessity of publishing information about records of this species in Poland.

Jacentkovsky's (1942) description of Pollenia moravica is restricted to the male sex only ("q unbekannt"). Rognes (1991) verified two characters useful for separating specimens of $P$. amentaria and $P$. moravica: the apparently broader frons of male (3-4 times as wide as median ocellus) and evenly 'dusted' abdomen with tessellation clearly visible in oblique posterior view in both sexes of $P$. moravica (Figs $1 \& 3$ ). In $P$. amentaria, the width of frons in males is about 1.0-1.5 times as wide as median ocellus, whereas the abdomen in both sexes is without tessellation (Figs 2,4). During the preparation of a data matrix for cladistic analysis, Rognes (1992) checked 41 other characters of the adult morphology, all of which showed the same state for $P$. amentaria and $P$. moravica; however, a thorough description of both male and female of P. moravica was never published. Rognes' statement (1991) that there are no 
differences between these species has been confirmed: it is found that the morphology of genitalia of the male ( 3 exx.) and the female ( 3 exx.) of the Polish P. moravica specimens (Figs 5-9) do not differ from the morphology of genitalia of the Polish $P$. amentaria specimens. Further research based on molecular methods would seem to be necessary to support the validity of $P$. moravica as a distinct species.

\section{ACKNOWLEDGMENTS}

We are grateful to Daniel Whitmore (Centro Nazionale Biodiversità Forestale, Verona, Italy) for language correction and commenting on the manuscript.

\section{REFERENCES}

DRABER-MoŃko A. 1985. Parasitoids of earthworms of the genera Pollenia R.-D. and Sarcophaga Meig. in the urban green of Warsaw and in some habitats of the Mazovian Lowlands. Fragmenta Faunistica 29: 311-375.

Draber-MońKo A. 2004. Calliphoridae. Plujki (Insecta: Diptera). Fauna Poloniae, 23. Fundacja Natura Optima Dux Muzeum i Instytut Zoologii, PAN, Warszawa, 662 pp.

DRABER-Mońko A. 2007. Plujki (Calliphoridae). In: BogdanowiCz W., ChUdzicka E., PilIPIUK I. \& SkiBIíska E. (eds), Fauna of Poland - characteristics and checklist of species, pp. 147-150, 230-231. Muzeum i Instytut Zoologii PAN, Warszawa, 2, 505 pp.

JACENTKOVSKÝ D. 1942. Beitrag zur Kenntnis der Gattung Pollenia R.-D. (Calliphoridae, Tachinoidae, Diptera). Abhandlungen der russischen Forschungsgesellschaft in Prag, 11 (16), 84: 193-225.

MERZ B. \& HAENNI J.-P. 2000. 1.1. Morphology and terminology of adult Diptera (other than terminalia). In: PAPP L. \& DARVAS B. (eds), Contributions to a Manual of Palaearctic Diptera (with special reference to flies of economic importance), vol. 1, pp. 21-51. General and Applied Dipterology, Science Herald Press, Budapest, 978 pp.

RoGNES K. 1987. New species in the intermedia-group and a new synonymy in the genus Pollenia RobineauDesvoidy, 1830 (Diptera: Calliphoridae). Systemnatic Entomology 12: 381-388.

ROGNES K. 1988. The taxonomy and phylogenetic relationships of the Pollenia semicinerea species group (Diptera, Calliphoridae). Systemnatic Entomology 13: 315-345.

ROGNES K. 1991. Blowflies (Diptera, Calliphoridae) of Fennoscandia and Denmark. Fauna Entomologica Scandinavica, vol. 24. E. J. Brill/Scandinavian Science Press, Leiden, 272 pp.

Rognes K. 1992. Revision of the cluster-flies of the Pollenia venturii species-group, with a cladistic analysis of Palaearctic species of Pollenia Robineau-Desvoidy (Diptera: Calliporidae). Entomologica scandinavica 23: 233-248.

ROGNES K. 1998. 3.51. Family Calliphoridae, pp. 617-648. In: PAPP L. \& DARVAS B. (eds), Manual of Palaearctic Diptera, 3. Science Herald, Budapest, $880 \mathrm{pp}$.

ROGNES K. 2004. Calliphoridae. In: PAPE T. (ed.), Diptera: Brachycera. Fauna Europaea version 1.1, http://www.faunaeur.org.

SCHUMANN H. 1986. Family Calliphoridae. In: PAPP L. \& SoOS Á. (eds.), Catalogue of Palaearctic Diptera Calliphoridae - Sarcophagidae, vol. 12, pp. 11-58. Akadémiai Kiadó Budapest, 265 pp.

SZPILA K. \& PAPE, T. 2007. Rediscovery, redescription and reclassification of Beludzhia phylloteliptera (Diptera: Sarcophagidae: Miltogramminae). European Journal of Entomology 104: 119-137.

ZuMPT F. 1956. 64I. CALLiPhorinaE. In: E. LindnER (ed.), Die Fliegen der palaearktischen Region, Stuttgart, E. Schweizerbart'sche Verlagsbuchhandlung 11: 1-140.

\section{STRESZCZENIE}

\section{[Pollenia moravica (Jacentkovský, 1941) (Diptera: Calliphoridae) - gatunek nowy dla fauny Polski]}

Dzięki badaniom faunistycznym prowadzonym w południowej Polsce $\mathrm{i}$ analizie zbiorów Muzeum i Instytutu Zoologii PAN wykryto występowanie kolejnego gatunku plujek na obszarze Polski - Pollenia moravica (Jacentk.). Status tego gatunku byl w przeszlości kwestionowany. Jednak w najnowszej kladystycznej analizie filogenezy rodzaju jest on traktowany jako wiarygodny takson, który ostatnio został włączony do listy europejskich gatunków Calliphoridae. Przekonało to autorów o konieczności publikacji informacji o występowaniu P. moravica (Jacentk.) w Polsce. 